\title{
PENERAPAN ASAS KEPATUTAN DALAM PERJANJIAN KAWIN
}

\section{Rumi Suwardiyati ${ }^{1}$}

${ }^{1}$ Fakultas Hukum, Universitas Brawijaya, email: rumisuwardivati@ub.ac.id

\begin{abstract}
ABSTRAK
Penelitian ini bertujuan untuk mengemukakan permasalahan mengenai asas kepatutan dalam perjanjian kawin yang mana dalam perkembangannya mengenai perjanjian kawin mulai merubah konsep dimana tidak hanya mengatur mengenai harta benda dalam perkawinan, dimungkinkan perjanjian kawin diartikan seperti perjanjian pada umumnya. Masalah yang diteliti adalah bagaimana penerapan asas kepatutan dalam perjanjian kawin. Metode yang dipakai dalam penelitian ini adalah penelitian hukum normatif dengan menggunakan pendekatan perundang-undangan dan pendekatan konsep, pengumpulan bahan hukum dengan studi pustaka yang dianalisis dengan metode interprestasi teleologis. Sehingga dapat disimpulkan bahwa belum dilakukan penerapan asas kepatutan dalam perjanjian kawin tersebut karena masih ada klausula yang dianggap tidak sesuai dengan moralitas.
\end{abstract}

\section{ARTICLE INFO}

\section{Kata Kunci:}

Asas Kepatutan;

Perjanjian Kawin; Harta

Benda Dalam

Perkawinan

Cite this paper:

Suwardiyati, R., 2020.

Penerapan Asas

Kepatutan Dalam

Perjanjian Kawin.

Widya Yuridika: Jurnal

Hukum, 3(2).

\section{PENDAHULUAN}

Manusia merupakan makhluk sosial atau biasa disebut dengan zoon politicon, yang mana mereka selalu hidup berkelompok. Hidup berkelompok tersebut disebut dengan masyarakat. Berjuta-juta manfaat dapat diambil oleh manusia lewat hidup bersama, baik dalam urusan pemenuhan kebutuhan hayati raga dan jiwanya. Bahkan cara hidup berdampingan serta berinteraksi dengan sesamanya, kian menjadi mudah memenuhi segala jenis kebutuhan yang diperlukan. ${ }^{1}$

Dalam memenuhi kebutuhan hidupnya selalu membutuhkan orang lain, keterikatan tersebut memunculkan suatu aturan yang mana hak dan kewajiban seseorang dapat terlindungi. Adapun dalam berinteraksi tersebut seperti adanya suatu perkawinan

1 Moch Isnaeni, Hukum Perkawinan Indonesia (Surabaya : PT. Revka Petra Media), hlm. 3 
yang mana dimuali dari rasa ketertarikan antara dua individu yang belainan jenis. Dengan ketertarikan tersebut muncul rasa memiliki, dimana rasa memiliki tersebut akan dimulai dengan suatu peristiwa hukum yaitu perkawinan. Perkawinan merupakan media untuk membetuk kelurga, karena dengan membentuk suatu keluarga wajib dimulai dengan suatu perkawinan.

Pengaturan perkawinan sebelum Undang-Undang Nomor 1 Tahun 1974 tentang Perkawinan (untuk selanjutnya disebut UUP) diatur dalam Kitab Undang-Undang Hukum Perdata (untuk selanjutnya disebut BW). Definisi perkawinan di dalam BW tidak ada hanya menjelaskan bahwa lembaga perkawinan hanya terlihat dari segi perdatanya. Pasal 26 BW menyatakan "Undang-undang memandang soal perkawinan hanya dalam hubungan-hubungan perdata". Pengertian perkawinan tidak dijelaskan namun lebih mengedepankan sifat pentingnya inti hubungan pria dan wanita yang melukan perkawinan. $^{2}$

Dalam perkembangan jaman yang semakin pesat menuntut seseorang dalam hidup dan kehidupan selalu memperhitungkan untung dan rugi. Saat akan melaksanakan suatu perkawinan tidak menjadi suatu hal yang tabu bagi mempelai untuk membuat suatu perjanjian kawin yang subtansinya mengenai pemisahan harta ataupun menyatukan harta mereka. Kemunculan Pasal 29 UUP tentang perjanjian kawin dikehendaki sebagai kebutuhan calon mempelai untuk menentukan kehendaknya sebelum melakukan perkawinan. Yang mana maksud dari pembuatan perjanjian kawin tersebut untuk meminimalisir apabila ada konflik dalam perkawinan mereka.

Perjanjian kawin tersebut diatur dalam BW, UUP dan Kompilasi Hukum Islam. Perjanjian kawin (huwelijks atau huwelijkse voorwaarden) adalah perjanjian yang dibuat oleh dua orang calon suami isteri sebelum dilangsungkannya perkawinan mereka, untuk mengatur akibat-akibat perkawinan yang menyangku harta kekayaan. ${ }^{3}$ Perjanjian kawin ini lebih bersifat hukum keluarga sehingga tidak semua ketentuan hukum perjanjian yang terdapat dalam buku III BW berlaku dalam perjanjian kawin.

Dalam pembuatan perjanjian kawin tersebut substansi yang akan disepakati oleh para pihak yang membuatnya tidak boleh bertentangan dengan Undang-Undang, agama, ketertiban umum, kesusilaan dan kepatutan. Dan perlu diketahui oleh Notaris terkait dengan perjanjian kawin hanya membahas terkait pemisahan atau penyatuan harta perkawinan (hanya mengatur tentang harta kekayaan). Namun perjanjian kawin yang dibuat oleh para pihak di Notaris $\mathrm{X}$ yang isi perjanjian kawin adalah tidak dibolehkannya dalam perkawinan memiliki keturunan. Salah satu tujuan perkawinan adalah memperoleh keturunan, apabila isi dari perjanjian kawin menyepakati hal tersebut maka bertolak belakang dengan asas-asas perjanjian meskipun para pihak saling sepakat akan isi tersebut. Dari latar belakang adanya isi perjanjian kawin tersebut, penulis akan membahas dan menganalisi permasalahan yang terkait dengan judul "PENERAPAN ASAS KEPATUTAN DALAM PERJANJIAN KAWIN ". Adapun tujuan dari penelitian ini adalah untuk mengemukakan permasalahan mengenai asas kepatutan dalam perjanjian kawin yang mana dalam perkembangannya mengenai perjanjian kawin mulai merubah konsep dimana tidak hanya mengatur mengenai harta benda dalam perkawinan, namun

\footnotetext{
2 ibid, hlm 71

3 Soetojo Prawirohamidjojo dan Marthalena Pohan, Hukum Orang dan Keluarga, (Surabaya: Airlangga University Press, 1995), hlm. 74
} 
membahas diluar harta benda dalam perkawinan. Apbila yang dibahas bukan harta benda dalam perkawinan maka perlu dilihat apakah isi dari perjanjian kawin tersebut telah menerapkan asas kepatutan di dalamnya.

Penelitian ini mempergunakan metode penelitian normatif, dengan pendekatan perundang-undang dan konseptual. Bahan hukum diperoleh dengan menggunakan studi kepustakaan dan dianalisis menggunakan penafsiran teleologis yang menekankan pada penerapat suatu asa dalam perjanjian guna tercipta isi perjanjian sesuai dengan kebutuhan masyarakat.

\section{HASIL DAN PEMBAHASAN}

Perjanjian kawin memang telah diautur dalam KUHPdt, namun pada saat pemberlakuan KUHPdt di Indonesia, jarang sekali orang yang akan membuat perjanjian kawin saat akan melangsungkan perkawinan. Namun dengan berkembangnya zaman, banyak pasangan yang akan melangsungkan perkawinan membuat perjanjian kawin yang tujuannya adalah:

1. Memisahkan harta kekayaan antara suami dan istri sehingga harta kekayaan mereka tidak lagi bercampur. Hal ini dimaksudkan apabila mereka bercerai maka tidak ada harta gono gini atau perebutan harta kekayaan antara mereka.

2. Bertanggung jawab terhadap hutang masing-masing.

3. Apabila diantara mereka akan menjual harta maka tidak membutuhkan persetujuan dari pasangannya.

4. Terkait dengan fasilitas kredit yang mereka ajukan tidak perlu mendapatkan persetujuan dari pasangannya.

Ranah hukum perkawinan memang didominasi oleh ketentuan yang bersifat dwingend rech atau memaksa. Tujuan untuk sendi kehidupan masyarakat tetap berdiri kokoh karena ada suatu penyimpangan yang dilakukan oleh anggotanya. ${ }^{4}$ Perkawinan saat ini marak sekali dibautnya perjanjian kawin, yang mana dapat dibuat sebelum, pada saat dan setelah perkawinan. Isi dari penjanjian kawin hanya terkait dengan:

a. Perjanjian kawin tidak boleh bertentangan dengan Pasal 23 A.B dan Pasal 1335 KUHPdt yang menentukan bahwa perjanjian tidak boleh dibuat dengan sebab palsu atau terlarang;

b. Tidak boleh menyimpang dari hak yang timbul dari kekuasaan suami sebagai kepala perkawinan (diatur dalam Pasal 140 ayat (1)), hak yang timbul dari kekuasaan orang tua dan hak-hak yang telah ditentukan dalam undang-undang untuk mempelai yang hidup terlama;

c. Perjanjian kawin yang dibuat tidak boleh dengan tujuan untuk pelepasan ha katas harta peninggalan;

d. Tidak dibuat perjanjian bahwa salah satu pihak memikul hutang yang lebih besar;

e. Dalam pembuatan perjanjian kawin harus dijelaskan secara detail tidak boleh menggunakan kata-kata umum yang akan menimbilkan multitafsir dalam mengartikannya.

Tidak menutup kemungkinan para pihak yang akan membuat perjanjian kawin dengan klausula yang tidak umum, sebagai contoh dalam Akta Perjanjian Kawin Nomor 27/KWI/IX/2018, dalam perjanjian kawin tersebut menyebutkan tidak boleh memiliki keturunan. Apabila dilihat dari konsep perjanjian kawin hanya mengatur terkait dengan harta, namun dalam perkembangan jaman, isi dari perjanjian kawin tidak selalu terkait

${ }^{4}$ Moch. Isnaeni, Op.Cit., hlm. 147 
harta dalam perkawinan saja. Berpedoman pada asas yang ada dalam perjanjian yaitu asas kebebasan berkontrak, dalam bidang perkawinan tidak dimaknai sebebas atau seluas dalam lapangan hukum perjanjian.

Makna sepakat dalam hukum perjanjian berbeda dengan sepakat dalam ranah hukum perkawinan. Sepakat dalam hukum perkawinan merupakan arti sepakat untuk mematuhi ketentuan perkawinan. Oleh sebab itu mengapa dalam ranah hukum perkawinan dikategorikan hukum yang sifatnya memaksa. Menurut Moch Isnaeni ada beberapa pasal dalam UUP yang sifatnya mengatur (regelend rech), pasal yang dimaksud adalah Pasal 29 UUP. Penyimpangan terhadap pasal tersebut membawa dampak bahwa para pihak yang menyimpanginya telah sepakat.

Apabila dalam suatu perjanjian kawin yang isinya tidak hanya mengatur mengenai harta benda dalam perkawinan namun ada klausula yang saling sepakat untuk tidak memiliki keturunan maka, dalam perjanjian kawin perlukah adanya penerapan asas seperti yang ada dalam perjanjian pada umumnya. Dalam penelitian ini mencoba untuk menganalisis asas kepatutan dalam pembuatan perjanjian kawin.

Kata asas berasal dari Bahasa arab yaitu asas yang artinya adalah dasar, asas, fondasi dan aturan. ${ }^{5}$ Terkait dengan pengertian asas atau prinsip, dalam Bahasa belanda disebut "beginsel" atau "principle", dalam Bahasa latin disebut "principium" dengan pengertian sesuatu yang menjadi dasar tumpuan berfikir atau bertindak atau kebenaran yang menjadi pokok dasar dalam berpikir dan bertindak. ${ }^{6}$ Asas memiliki kedudukan hukum yang sangat penting dalam sistem hukum karena asas merupakan pondasi yang menopang kokohnya suatu norma. Memahami pengertian asas, beberapa ahli memberikan penjelasan terkait pengertian asas hukum yaitu sebagai berikut:

1. Menurut Bellefroid, asas hukum adalah norma dasar yang dijabarkan dalam hukum positif. Jadi asas hukum merupakan kristalisasi (pengendapan) hukum positif dalam suatu masyarakat. ${ }^{7}$

2. Menurut van Eikema Homes, asas bukan merupakan norma hukum yang konkrit tetapi hanya sebagai dasar atau petunjuk bagi hukum.

3. Menurut Paul Scholten, asas hukum merupakan pikiran dasar.

Beberapa ahli hukum memberikan pendapat bahwa asas hukum merupakan hati atau jantung dari peraturan, hal tersebut didasari pemikiran: ${ }^{8}$

a. Asas hukum dianggap sebagai landasan yang paling luas bagi lahirnya norma hukum, oleh sebab itu norma hukum dapat dikembalikan pada asas yang dimkasud;

b. Asas hukum dianggap sebagai alasan bagi lahirnya norma hukum, hal tersebut disitilahkan sebagai ratio legis dari suatu norma. Asas hukum tidak akan habis kekuatannya dan akan tetap melahirkan norma-norma hukum baru.

5 Yasardin, Asas Kebebasan Berkontrak Syariah, (Jakarta : Prenadamedia Group, 2018), hlm. 68

6 Agus Yudha Hernoko, Asas Proporsionalitas dalam Kontrak Komersial, (Jakarta : Prenamedia Group. 2014), hlm. 18

7 Sudikno Mertokusumo, Mengenal Hukum, (Yogyakarta: Liberty, 2008), hlm. 34

8 Satjipto Raharjo, Ilmu Hukum, (Bandung: Citra Aditya Bakti, 2000), hlm. 45 
Pembahasan terkait dengan asas memang sangat penting, menurut Poerwodarminto memberikan pendapat bahwa asas sebagai kebenaran yang menjadi tumpuan berpikir atau berpendapat, sedangkan asas hukum diartikan sebagai suatu kebenaran yang dipergunakan sebagai tumpuan berpikir dan berpendapat dalam penegakan hukum. Terkait dengan asas kadang tidak dicantumkan secara jelas di dalam suatu aturan perundang-undangan, namun asas dapat dijadilan suatu rujukan apabila ada ketidakjelasan atau kekaburan suatu norma. Dalam rangka untuk menciptakan suatu keseimbangan dan memelihara hak yang dimiliki oleh para pihak, KUHPdt menjelaskan terkait dengan asas umum dalam suatu perjanjian. Asas merupakan patokan atau pedoman, serta menjadi batas atau rambu-rambu dalam mengatur dan membentuk suatu perjanjian yang akan dibuat oleh para pihak yang mana hal tersebut dijadikan undangundang bagi para pihak yang membuat perjanjian tersebut.

Nieuwenhiusmenyebutkan terkait dengan asas hukum memiliki dua landasan yaitu asas hukum berakar dalam kenyataan masayarakat dan kedua pada nilai-nilai yang dipilih sebagai pedoman oleh kehidupan bersama, penyatuan factor riil dan idiil hukum merupakan fungsi asas hukum. Asas hukum merupakan landasan yang paling luas bagi lahirnya suatu peraturan hukum, yang memberikan arti bahwa peraturan hukum pada akhirnya dapat dikembalikan kepada asas tersebut. ${ }^{9}$

Salah satu asas yang akan dijadikan isu utama dalam penelitian adalah asas kepatutan. Dalam Kamus Besar Bahasa Indonesia arti patut adalah baik, layak, sesuai, pantas, masuk akal, wajar dan sudah seharusnya atau sepantasnya. Asas kepatutan diartikan oleh Riduan Syahrani sebagai keseimbangan, keadilan membagi kerugian dan keuntungan antara para pihak yang membuat perjanjian. Kepatutan biasanya dipakai sebagai kebalikan hukum yang telah jelas, sebagai menambah ketentuan hukum, dimana keadilan menentukan isi dari perjanjian. ${ }^{10}$ Rasa keadilan dalam masyarakat merupakan tujuan dari asas kepatutan harus dipertahankan hal tersebut untuk mengukur tentang hubungan hukum tersebut. ${ }^{11}$ Syarat kepatutan sebetulnya berakar pada sifat peraturan hukum pada umumnya, dengan cara mengadakan keseimbangan dari beberapa kepentingan para pihak. Pada hakekatnya tidak diperbolehkan suatu kepentingan seseorang dipenuhi yang akibatnya mendesak atau mengesampingkan kepentingan orang lain atau mengabaikan sehingga menimbulakn ketidak seimbangan. ${ }^{12}$ Terkait dengan kepatutan tidak dapat dipisahkan dengan iktikad baik, karena keduanya sangat penting dalam hal pelaksanaan persetujuan. ${ }^{13}$

Dalam symposium Hukum Perdata Nasional yang diselenggarakan oleh Badan Pembinaan Hukum Nasional (BPHN), iktikad baik diartikan sebagai: ${ }^{14}$

1. Kejujuran pada saat pembuatan perjanjian;

\footnotetext{
9 Rachmi Sulistyarini, Makna Asas Kebebasan Berkontrak Dalam Hukum Perjanjian Menurut Hukum Indonesia, (Ringkasan Desertasi), Program Pascasarjana Universitas Brawijaya, Malang, 2018, hlm. 25

10 Riduan Syahrani, Kata-Kata Kunci Mempelajari Ilmu Hukum, (Bandung : PT. Alumni, 2009), hlm. 123

11 Mariam Darus Badrulzaman dkk, Kompilasi Hukum Perikatan, (Bandung : PT. Citra Aditya Bakti, 2001), hlm. 89

12 Ibid, hlm. 84-85

13 Wirjono Projodikoro, Asas-Asas Hukum Perjanjian, (Bandung : Sumur Bandung, 1960), hlm. 83

14 Badan Pembinaan Hukum Nasional (BPHN), Simposium Hukum Perdata Nasional, Kerjasama Badan Pembinaan Hukum Nasional (BPHN), Fakultas Hukum Universitas Gadjah Mada, Yogyakarta 21-23 Desember 1981.
} 
2. Para pihak dianggap beriktikad baik pada saat tahap pembuatan perjanjian yang dilakukan di depan pejabat;

3. Sebagai kepatutan dalam tahap pelaksanaan yaitu terkait dengan penilaian baik terhadap perilaku para pihak dalam melaksanakan apa yang telah mereka sepakati yang tujuannya untuk mencegah perilaku yang tidak patut dalam pelaksanaan perjanjian tersebut.

Membahas terkait iktikad baik acapkali tumpeng tindih dengan kewajaran dan kepatutan (redelijkheid en billijkheid; reasonableness and equity), dalam iktikad baik terkandung kepatutan demikian juga sebaliknya dalam kepatutan muncul iktikad baik. ${ }^{15}$ Oleh sebab itu dalam praktik di pengadilan, iktikad baik dan kepatutan dipahami sebagai asas atau prinsip yang saling melengkapi (complementary). ${ }^{16}$ Antara satu asas dengan asas yang lain saling berkaitan, dalam iktikad baik ada kelayakan dan kepatutan. Kelayakan berkaitan dengan ratio sedangkan kepatutan berkaitan dengan moral yang selanjutnya disebut dengan kepantasan. Dalam pembuatan perjanjian kawin hendaknya para pihak memahami bahwa isi dari perjanian kawin harus menerapkan asas kepatutan agar isi atau causa dalam perjanjian kawin tersebut memenuhi causa yang halal.

Meskipun perjanjian kawin diartikan seperti perjanjian pada umumnya yang mengakomodir asas kebebasan berkontrak, namun penerapan asas kebebasan berkontrak dalam perjanjian kawin tidak dapat disamakan seperti perjanjian pada umumnya. Selain melihat beberapa asas dalam perjanjian, asas kepatutan harus dilaksanakan dalam pembuatan perjanjian kawin dengan tujuan makna perkawinan itu sendiri dapat terwujud. Adapun tujuan perkawinan menurut Undang-Undang Perkawinan adalah membentuk keluarga (rumah tangga) yang bahagia dan kekal berdasarkan Ketuhanan Yang Maha Esa. Adapun dalam Kompilasi Hukum Islam menyebutkan bahwa tujuan perkawinan untuk mewujudkan kehidupan rumah tangga yang sakinah, mawaddah dan rahmah. Adapun tujuan perkawinan menurut hukum islam adalah sebagai berikut: ${ }^{17}$

a. Menghalalkan hubungan kelamin antara seorang pria dan wanita untuk memenuhi tuntutan hajat tabiat kemanusiaan;

b. Membentuk atau mewujudkan satu keluarga yang damai, tenteram dan kekal dengan dasar cinta dan kasih sayang;

c. Memperoleh keturunan yang sah yang akan melangsungkan keturuanan serta memperkembangkan suku-suku bangsa manusia.

Dari beberapa tujuan perkawinan salah satunya yaitu memperoleh keturunan, apabila dalam pembuatan perjanjian kawin ada klausula pelarangan memiliki keturunan maka hal tersebut tidak sesuai dengan tujuan perkawinan, penerapan asas kepatutan dapat dijadikan tolok ukur apakah perjanjian kawin patut ataukah tidak. Syarat sah

\footnotetext{
${ }^{15}$ Agus Yudha Hernoko, Op. cit., hlm. 124

${ }^{16}$ Sogar Simamora, Prinsip Hukum Kontrak Dalam Pengadaan Barang dan Jasa oleh Pemerintah, (Ringkasan Desertasi), Program Pascasarjana Universitas Airlangga, Surabaya, 2005, hlm.39

${ }^{17}$ Abdul Ghofur Anshori, Hukum Perkawiann Islam Perspektif Fikih dan Hukum Positif, (Yogyakarta: UII Press Yogyakarta, 2011), hlm. 175
} 
perjanjian diatur dalam Pasal 1320 KUHPdt namun ada beberapa syarat diluar yang diatur dalam Pasal tersebut adalah sebagai berikut: ${ }^{18}$

1. Kontrak harus dilaksanakan dengan Itikad Baik;

2. Kontrak harus sesuai dengan asas kepatutan;

3. Kontrak tidak melanggar prinsip kepentingan umum;

4. Kontrak harus sesuai dengan kebiasaan.

Dalam pembuatan perjanjian kawin dimungkinkan diawali dengan suatu perbedaan, perumusan kesepakatan diawali dengan adanya negosiasi para pihak yang membuat perjanjian. Dalam posisi negosiasi dimungkinkan ada suatu penyalahgunaan keadaan (misbruk van omstandigheden). Penyalahgunaan keadaan merupakan bentuk cacat kehendak yang baru dalam sisitem hukum perjanian hukum Belanda, yang mana hal tersebut mengadopsi dari hukum inggris. Penyalahgunaan keadaan dalam sistem common law merupakan doktrin yang menentukan pembatalan perjanjian yang dibuat berdasarkan tekanan yang tidak patut, tetapi tidak termasuk dalam kategori paksaan. ${ }^{19}$ Pengertian dari penyalahgunaan keadaan adalah suatu keadaan untuk menyalahgunakan keadaan darurat orang lain, ketergantungannya/ ketidakberdayaannya, kesembronoannya, keadaan akalnya yang tidak sehat atau ketiadaan pengalamnnya dalam mengerjakan perbuatan hukum yang merugikan dirinya. ${ }^{20}$

Van Dunne membedakan penyalahgunaan karena keunggulan ekonomis dan keunggulan kejiwaan dengan uraian sebagai berikut: ${ }^{21}$

a) Persyaratan untuk penyalahgunaan keunggulan ekonomis;

1. Pihak yang lain harus mempunyai keunggulan ekonomis;

2. Pihak lain terpaksa mengadakan perjanjian.

b) Persyaratan untuk adanya penyalahgunaan keunggulan kejiwaan;

1. Salah satu pihak menyalahgunakan ketergantungan relative, seperti hubungan kepercayaan istimewa antara orang tua dan anak, suami isteri, dokter pasien;

2. Salah satu pihak menyalahgunakan keadaan jiwa yang istimewa dari pihak lawan seperti adanya gangguan jiwa, tidak berpengalaman, gegabah, kurang pengetahuan, kondisi badan tidak baik.

c) Unsur kerugian bagi satu pihak;

d) Unsur penyalahgunaan kesempatan oleh pihak lain. yaitu:22

Ada 4 (empat) perkembangan lanjut menurut Van Dunne terkait penyalahgunaan

a. Berlakunya asas iktikad baik secara terbatas;

b. Penjelasan normative dari perbuatan hukum;

c. Pembatasan berlakunya persyaratan standar;

\footnotetext{
${ }_{18}$ Munir Fuady, Hukum Kontrak (Dari Sudut Pandang Hukum Bisnis), (Bandung: PT. Citra Aditya Bakti, 1999), hlm. 81

${ }^{19}$ Ridwan Khairandy (II),Op. Cit, hlm 227

${ }^{20}$ Fockema Andreae, Kamus Istilah Hukum, (Jakarta: Binacipta, 1983), hlm. 302

${ }^{21}$ Henry P Panggabean, Penyalahgunaan Keadaan (Misbruik van Omstandigheiden) Sebagai Alasan Baru Untuk Pembatalan Perjanjian (Berbagai Perkembangan Hukum di Belanda), (Ypgyakarta: Liberty, 2001), hlm. 44

22 Ibid.
} 
d. Penyalahgunaan hak.

Menurut Satrio ada beberapa factor penyalahgunaan keadaan yang terjadi pada saat menutup perjanjian, hal tersebut dikarenakan: ${ }^{23}$

1. Adanya keunggulan ekonomis yang menekan, seperti kesulitan keuangan yang mendesak;

2. Adanya hubungan atasan dan bawahan, keunggulan ekonomis pada satu pihak;

3. Adanya keadaan lain yang tidak menguntungkan seperti pasien yang membutuhkan dokter;

4. Perjanjian tersebut mengandung hubungan yang timpang dalam kewajiban timbal balik diantara para pihak;

5. Kerugian yang sangat besar bagi salah satu pihak.

Adapun syarat terjadinya penyalahgunaan keadaan menurut Nieuwenhuisadalah sebagai berikut: ${ }^{24}$

a) Terdapat keadaan istimewa (bijzonedere omstandigheden), sebagai contoh keadaan darurat, ketergantungan, ceroboh, jiwa yang kurang waras;

b) Terdapat suatu keadaan nyata (kenbaarheid);

c) Terdapat penyalahgunaan (misbruik);

d) Terdapat hubungan kausal (causal verband).

Penyalahgunaan yang telah dibahas di atas memiliki kaitan erat dengan posisi para pihak yang akan membuat perjanjian. Posisi para pihak sebelum mencapai kata sepakat berperan besar ada kemungkinan ada atau tidaknya penyalahgunaan keadaan, karena hal tersebut dapat dipengaruhi dari faktor ekonomis dan psikologis. Aspek posisi para pihak pada fase kontraktual, dimana perjanjian lahir karena ada kata sepakat dari kedua belah pihak. Adanya persesuaian kehendak atau keinginan yang sama maka lahir suatu perjanjian. Dalam hal ini yaitu perjanjian kawin yang mana awal sebelum menikah, psikologis seseorang yang didominasi rasa maka mudah untuk menekan posisi pasangan. Pasangan akan mudah untuk menyepakati isi perjanjian, meskipun isi dari perjanjian kawin tersebut tidak sesuai dengan tujuan perkawinan, dan tidak menerapkan asas kepatutan.

Selain melihat dari posisi para pihak sebelum membuat perjanjian, maka perlu dilihat terkait dengan isi perjanjian tersebut. Apabila dilihat dari aspek ekonomis, yang lemah memiliki posisi lemah "bergantung" sehingga untuk mendapatkan prestasi tertentu sangat dibutuhkan, ia terpaksa menerima isi dari perjanjian yang merugikan dirinya. ${ }^{25}$ Penyalahgunaan secara psikologis juga dimungkinkan yaitu penyalahgunaan ketergantungan relative dari calon mempelai atau suami istri, yang menyebabkan kata sepakat itu ada meskipun merugikan salah satu pihak. Adanya kesepakatan yang muncul akibat penyalahgunaan keadaan tidak membuat perjanjian bertentangan dengan kesusilaan namun keadaan yang mengiringi terjadinya kata sepakat tersebut bertentangan dengan kesusilaan.

\footnotetext{
23 J. Satrio, Hukum Perjanjian (Perjanjian Pada Umumnya), (Bandung: Citra Aditya Bakti, 1992), hlm. 152

${ }^{24}$ Henry P Panggabean, Op. Cit., hlm 40

${ }^{25}$ Rendy Saputra, Kedudukan Penyalahgunaan Keadaan (MISBRUIK VAN OMSTANDIGHEDEN) Daalm Hukum Perjanjian Indonesia, (Yogyakarta: Gadjah Mada University Press, 2016), hlm63
} 
Penyalahgunaan keadaan dapat mengakibatkan suatu perjanjian tidak memiliki kekuatan hukum, kalua perjanjian tersebut diadakan dengan bertolak dari suatu penyebab yang bertentangan dengan moralitas yang baik dan penggunaan keadaan yang mengakibatkan pihak lawantidak dapat mengambil putusan yang bersifat independen. ${ }^{26}$ Aspek moralitas memberikan nuansa iktikad baik, kewajaran serta keadilan. Dan dalam aspek yuridis melahirkan jaminan kepastian hukum atas komponen yang mencakup siklus hidup. ${ }^{27}$

Teori mengenai moralitas hukum bermula dari asumsi antropologis tentang kebebasan yang dimilki oleh manusia. Beberapa doktrin modern mempercayai bahwa manusia secara kodrati menenteng kebebasan. ${ }^{28}$ Dalam konteks pembuatan perjanjian, aspek moralitas jangan diartikan hanya sebagai moralitas aturan, tetapi juga moralitas dalam berperilaku dan jangan sampai hal tersebut mengabaikan kepentingan umum. Aspek moralitas erat kaitannya dengan kepantasan dan kepatutan, dalam pembuatan perjanjian moralitas menjelma menjadi kewajiban umum yang dikenal sebagai iktikad baik. Menurut Hoge Raad, iktikad baik ini merupakan doktrin yang merujuk pada kerasionalan dan kepatutan. Dalam pembuatan perjanjian harus dilaksanakan menurut kerasionalan dan kepatutan.

Oleh sebab itu dalam pembuatan perjanjian kawin, penerapan asas kepatutan sangat diutamakan karena ada kaitannya dengan iktikad baik, apabila dijabarkan rasionalitas yang dimaksud merupakan kepantasan secara rasio sedangkan kepatutan merupakan kepantasan secara moral. Penerapan asas kepatutan dalam perjanjian kawin merupakan penjabaran dari kepantasan secara moral, yang mana isi dalam perjanjian tersebut harus melihat dari kewajaran publik baik dalam isi ataupun pelaksanaanya.

\section{PENUTUP}

Berdasarkan hasil penelitian dan pembahasan mengenai penerapan asas kepatutan dalam perjanjian kawin, asas kepatutan berkaitan erat dengan asas iktikad baik, kedua asas tersebut saling melengkapi. Dalam asas iktikad baik dapat ditemukan adanya kepatutan dan kelayakan. Terkait kepatutan ada dalam Pasal 1339 KUHPdt namun tidak memberikan definisi kepatutan. Sehingga dapat diartikan bahwa kepatutan berkaitan erat dengan moralitas.

Dimungkinkan terkait dengan isi dari perjanjian kawin yang tidak menerapkan asas kepatutan dipengarui adanya penyalahgunaan keadaan, penyalahgunaan keadaan tersebut dapat muncul dari factor ekonomis dan psikologis dari salah satu pihak sehingga muncul kesepakatan isi dari perjanjian kawin tersebut. Dalam hal ini aspek moralitas sangat diperlukan dalam penerapan asas kepatutan karena dapat diartikan bahwa kepatutan merupakan kepantasan secara moral. Sehingga dapat disimpulkan bahwa belum dilakukan penerapan asas kepatutan dalam perjanjian kawin tersebut karena masih ada klausula yang dianggap tidak sesuai dengan moralitas. Dan kesepakatan tersebut yang seolah-olah isinya telah disepakati oleh kedua belah pihak dimungkinkan dalam prosesnya, salah satu pihak melakukan penyalahgunaan keadaan.

Saran Notaris harus memahami terkait dengan tugas dan jabatannya, dalam pembuatan perjanjian kawin menjadi kewenangan Notaris untuk membuatnya, meskipun

${ }^{26}$ Ridwan Khairandy (II), Op. Cit., hlm. 232

27 Rendy Saputra, Op. Cit., hlm. 67

28 Franz Magnis, Etika Dasar: Masalah Pokok Filsafat Moral, (Yogyakarta: Kanisius, 1989), hlm. 8 
dengan dasar asas kebebasan berkontrak namun dalam pembuatan perjanjian kawin tidak dapat asas kebebasan berkontrak dimaknai luas seperti perjanjian dalam buku ketiga KUHPdt, karena ada tujuan yang lebih penting dalam perkawinan itu sendiri. Notaris setidaknya memberikan pemahaman kepada para pihak yang akan membuat perjanjian kawin tersebut untuk tidak memperjanjikan sesuatu yang tidak sesuai dengan kepatutan, maksud kepatutan adalah kepantasan dalam aspek moralitas. Adapun bagi masyarakat yang akan membuat perjanjian kawin hendaklah memahami konsep perjanjian kawin yang diatur dalam Undang-Undang Perkawinan, Kompilasi Hukum Islam dan KUHPdt dengan cara menanyakan kepada Notaris atau ahli hukum, sehingga isi dari perjanjian kawin tersebut tidak betentangan dengan kepatutan, kesusilaan dan Undang-Undang Yang berlaku.

\section{DAFTAR PUSTAKA}

Andreae, Fockema. 1983. Kamus Istilah Hukum, Jakarta: Binacipta, 1983

Anshori, Abdul Ghofur. 2011. Hukum Perkawiann Islam Perspektif Fikih dan Hukum Positif, Yogyakarta: UII Press Yogyakarta.

Badrulzaman, Mariam Darus dkk. 2001. Kompilasi Hukum Perikatan, Bandung : PT. Citra Aditya Bakti.

Badan Pembinaan Hukum Nasional (BPHN), Simposium Hukum Perdata Nasional, Kerjasama Badan Pembinaan Hukum Nasional (BPHN), Fakultas Hukum Universitas Gadjah Mada, Yogyakarta 21-23 Desember 1981.

Fuady, Munir. 1999. Hukum Kontrak (Dari Sudut Pandang Hukum Bisnis), Bandung: PT. Citra Aditya Bakti.

Hernoko, Agus Yudha. 2014. Asas Proporsionalitas dalam Kontrak Komersial, Jakarta : Prenamedia Group. 2014

Isnaeni, Moch. 2016. Hukum Perkawinan Indonesia, Surabaya : PT. Revka Petra Media

Magnis, Franz. 1989. Etika Dasar: Masalah Pokok Filsafat Moral, Yogyakarta: Kanisius.

Mertokusumo, Sudikno. 2008. Mengenal Hukum, Yogyakarta: Liberty.

Panggabean, Henry. 2001. Penyalahgunaan Keadaan (Misbruik van Omstandigheiden) Sebagai Alasan Baru Untuk Pembatalan Perjanjian (Berbagai Perkembangan Hukum di Belanda), Yogyakarta: Liberty.

Prawirohamidjojo, Soetojo dan Marthalena Pohan. 1995. Hukum Orang dan Keluarga, Surabaya: Airlangga University Press.

Prodjodikoro, Wirjono. 1960. Asas-Asas Hukum Perjanjian, Bandung : Sumur Bandung.

Raharjo, Satjipto. 2000. Ilmu Hukum, Bandung: Citra Aditya Bakti.

Satrio,J. 1992. Hukum Perjanjian (Perjanjian Pada Umumnya), Bandung: Citra Aditya Bakti. 
Saputra, Rendy. 2016. Kedudukan Penyalahgunaan Keadaan (MISBRUIK VAN OMSTANDIGHEDEN) Daalm Hukum Perjanjian Indonesia, Yogyakarta: Gadjah Mada University Press.

Sulistyarini, Rachmi. 2018. Makna Asas Kebebasan Berkontrak Dalam Hukum Perjanjian Menurut Hukum Indonesia, (Ringkasan Desertasi), Program Pascasarjana Universitas Brawijaya, Malang.

Syahrani, Riduan. 2009. Kata-Kata Kunci Mempelajari Ilmu Hukum, Bandung : PT. Alumni.

Simamora, Sogar. 2005. Prinsip Hukum Kontrak Dalam Pengadaan Barang dan Jasa oleh Pemerintah, (Ringkasan Desertasi), Program Pascasarjana Universitas Airlangga, Surabaya

Yasardin. 2018. Asas Kebebasan Berkontrak Syariah, Jakarta : Prenadamedia Group. 
